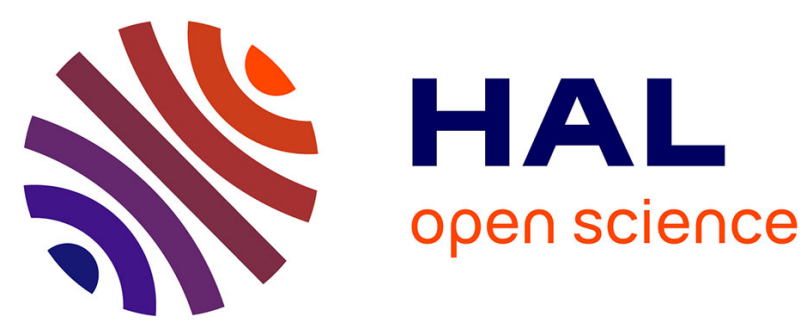

\title{
Copper tolerance and accumulation in two cuprophytes of South Central Africa:Crepidorhopalon perennis and C. tenuis (Linderniaceae)
}

Michel-Pierre Faucon, François Chipeng, Nathalie Verbruggen, Grégory Mahy, Gilles Colinet, Mylor Shutcha, Olivier Pourret, Pierre Meerts

\section{To cite this version:}

Michel-Pierre Faucon, François Chipeng, Nathalie Verbruggen, Grégory Mahy, Gilles Colinet, et al.. Copper tolerance and accumulation in two cuprophytes of South Central Africa:Crepidorhopalon perennis and C. tenuis (Linderniaceae). Environmental and Experimental Botany, 2012, 84, pp.11-16. 10.1016/j.envexpbot.2012.04.012 . hal-02265583

\section{HAL Id: hal-02265583 https://hal.science/hal-02265583}

Submitted on 10 Aug 2019

HAL is a multi-disciplinary open access archive for the deposit and dissemination of scientific research documents, whether they are published or not. The documents may come from teaching and research institutions in France or abroad, or from public or private research centers.
L'archive ouverte pluridisciplinaire HAL, est destinée au dépôt et à la diffusion de documents scientifiques de niveau recherche, publiés ou non, émanant des établissements d'enseignement et de recherche français ou étrangers, des laboratoires publics ou privés. 
1 Copper tolerance and accumulation in two cuprophytes of South Central Africa:

2 Crepidorhopalon perennis and C. tenuis (Linderniaceae)

3

4 Michel-Pierre Faucon $^{\mathrm{a}, \mathrm{b}, *}$, François Chipeng ${ }^{\mathrm{c}, \mathrm{d}}$, Nathalie Verbruggen ${ }^{\mathrm{d}}$, Grégory Mahy ${ }^{\mathrm{e}}$, Gilles

5 Colinet $^{\mathrm{f}}$, Mylor Shutcha ${ }^{\mathrm{c}}$, Olivier Pourret ${ }^{\mathrm{b}}$, Pierre Meerts $^{\mathrm{a}}$

6 a Laboratoire d'Ecologie végétale et Biogéochimie, Université Libre de Bruxelles, Boulevard

7 du Triomphe. B-1050 Bruxelles, Belgium.

$8{ }^{\mathrm{b}}$ Hydrogéochimie Interactions Sol-Environnement (HydrISE). Institut Polytechnique LaSalle

9 Beauvais (IGAL-ISAB). 19 rue Pierre Waguet - BP 30313-F-60026 Beauvais, France

${ }^{\mathrm{c}}$ Université de Lubumbashi. Faculté des Sciences Agronomiques, Lubumbashi, Democratic 11 Republic of Congo.

${ }^{\text {d }}$ Laboratoire de Physiologie et de Génétique moléculaire des Plantes, Université Libre de

13 Bruxelles, Campus Plaine - CP242, Bld. du Triomphe, B-1050 Brussels, Belgium;

e Laboratory of Ecology. Université de Liège, Gembloux Agro-Bio Tech, Passage des

Déportés 2, B-5030 Gembloux, Belgium.

${ }^{\mathrm{f}}$ Laboratory of Geopedology. Université de Liège, Gembloux Agro-Bio Tech, Passage des

Déportés 2, B-5030 Gembloux, Belgium.

*corresponding author:

Michel-Pierre Faucon

E-mail address: michel-pierre.faucon@lasalle-beauvais.fr 


\section{ABSTRACT}

Crepidorhopalon perennis is an endemic metallophyte restricted to only one site on $\mathrm{Cu}$-rich soils in Katanga. Crepidorhopalon tenuis has a broader niche, from normal to $\mathrm{Cu}$-rich soils, but has high affinity for cupriferous habitats. Both plants have been considered as $\mathrm{Cu}-\mathrm{Co}$ accumulators. $\mathrm{Cu}$ tolerance and accumulation of $C$. tenuis were studied in axenic conditions in vitro in four metallicolous populations and one non-metallicolous population whereas for C. perennis only one population was investigated. Results showed a $\mathrm{Cu}$ tolerance of both $C$. tenuis and $C$. perennis. Variation of tolerance among metallicolous and non-metallicolous populations was also observed. The addition of $\mathrm{Cu}$ enhanced the growth of some metallicolous populations under sterile conditions, hence confirming the high needs in copper of metallicolous populations. This could represent a cost of tolerance which would explain the high affinity of species for cupriferous habitats. On the other hand, Crepidorhopalon perennis did not show the same features. Its restricted distribution may be explained by a cost of $\mathrm{Cu}$ tolerance. Crepidorhopalon perennis and C. tenuis are not $\mathrm{Cu}$ hyperaccumulators and seem to behave rather like excluder species.

Key words: copper tolerance, trace metals, copper accumulation, cost of tolerance

\section{Introduction}

Soil contamination by trace metals is a major environmental issue throughout the world (Alloway, 1995; Smith and Huyck, 1999; Baize and Tercé, 2002) in the last century as a consequence of the intensification of mining and mineral processing, which dispersed toxic trace metals leading to large contaminated areas. In this context, new types of metalliferous habitats, which did not exist or were rare before the industrial revolution, appeared on the Earth (Allen and Sheppard, 1971; Ginocchio et al., 2002). The soils of such habitats have concentrations of trace metals up to 1000 times higher than the "normal" soils, which hence gives them a high phytotoxicity (Ernst, 1974; Baker et al., 2000; Reeves and Baker, 2000). Only species that have adapted to these extreme soil conditions can grow in such 
contaminated habitats. The trace metals tolerance of plants is nowadays a research topic dealing mainly with the processes of adaptation to very restrictive environmental factors (Antonovics et al., 1971). Copper and zinc tolerance has been largely studied in some pseudometallophytes, hence contributing to a better understanding in terms of genetics and evolution of trace metals tolerance of such plants. Several studies on copper tolerance have highlighted the intensity of selection due to toxicity of trace metals (McNeilly and Bradshaw, 1968; Wu et al., 1975), heritability of tolerance (Macnair, 1981, 1983; Schat and Ten Bookum, 1992; Schat et al., 1993), cost of copper tolerance (Macnair et al., 2000), reproductive isolation (Macnair and Christie, 1983; Macnair and Gardner, 1998), and speciation (Macnair and Gardner, 1998).

Copper tolerance is little known particularly in species that grow only or show a frequency and/or high abundance on copper soils (Brooks and Malaisse, 1990; Harper et al. 1997; 1998), i.e. the cuprophytes (Duvigneaud and Denaeyer-De Smet, 1963; Ernst, 1974, 1990). Tolerance to extreme $\mathrm{Cu}$ concentrations in soils $\left(1-50 \mathrm{~g} \mathrm{~kg}^{-1}\right)$ was demonstrated experimentally only for a few cuprophytes such as Haumaniastrum katangense, $H$. robertii, Aeolanthus biformifolius (Lamiaceae) (Morrison et al., 1979; Chipeng et al., 2010; Peng et al., in press); Mimulus guttatus (Scrophulariaceae) (Allen and Sheppard, 1971; Macnair, 1983); Silene cobalticola (Caryophyllaceae) (Baker et al., 1983) and Elsholtzia haichowensis (Lou et al., 2004). The limited number of experimental studies in these cuprophytes, under the intrinsic value of biological material, may be partly explained by difficulty of cultivation in soils with low $\mathrm{Cu}$ concentrations (Malaisse and Brooks, 1982; Paton and Brooks, 1996). In fact, cuprophytes are known almost exclusively on copper soils of southern central Africa (Duvigneaud and Denaeyer-De Smet, 1963; Brooks and Malaisse, 1985). Among these, Crepidorhopalon tenuis (S. Moore) Eb. Fisch. (syn.: Lindernia damblonii P.A. Duvign. and L. tenuis S. Moore) (Linderniaceae) grows on soils with a wide range of $\mathrm{Cu}$ concentrations, including occasionally non-metalliferous soils (Faucon et al., 2009, 2011a). In contrast, Crepidorhopalon perennis (P.A. Duvign.) Eb. Fisch. (syn.: Lindernia perennis (P.A. Duvign.) is endemic to a single metalliferous site (Faucon et al., 2010) and occupies a narrow niche, growing on soils with extremely high concentrations of $\mathrm{Cu}$ and $\mathrm{Co}$ (Faucon et al., 2011a; Faucon et al., in press). In this context, the $C$. perennis- $C$. tenuis species pair appears to be a very promising model to investigate the relationship between the degree of tolerance of plant 
populations, copper bioavalaible content of sites and the ecological isolation of an endemic species.

In Crepidorholon perennis and $C$. tenuis, genuine cuprophily was assessed by examining the relationship between the concentration of copper in soil and plant biomass (Faucon et al., 2009, 2011a). It appeared that copper-tolerant populations showed lower fitness on non-metalliferous soil than non-tolerant populations and vice versa on copper soil. It seems that needs in essential metals are higher for tolerant populations than for non-tolerant plants (Macnair et al., 2000). Strict endemism on copper-rich soils could be explained by a “cost of copper tolerance" (Harper et al., 1997; Macnair et al., 2000; Tadros, 1957; Kazakou et al., 2008). However, the existence of a cost of copper tolerance was demonstrated only in Mimulus guttatus and remains highly controversial. Another hypothesis is that cuprophytes are very sensitive to pathogens of soil (Malaisse and Brooks, 1982; Paton and Brooks, 1996; Chipeng et al., 2010).

Thirty-two cuprophytes apparently have the capacity to accumulate copper in their top growth at concentrations above the threshold of $\mathrm{Cu}$ hyperaccumulation $\left(>1000 \mathrm{mg} \mathrm{kg}^{-1}\right.$, Baker and Brooks, 1989) (Reeves and Baker, 2000; Reeves, 2006). Nevertheless, There has been extensive discussion of the reliability of earlier data on $\mathrm{Cu}$ and $\mathrm{Co}$ accumulation, the wide variation of these element concentrations in a number of the African species, and the effects of contamination by dusts of secondary minerals of elements such as $\mathrm{Cu}$, e.g. in Reeves and Baker (2000). The validity of these concerns was demonstrated in the work of Faucon et al. (2007). Macnair (2000) states that $\mathrm{Cu}$ hyperaccumulation has not yet been observed in culture, but Küpper et al. (2009) found that Crassula helmsii could accumulate more $9000 \mathrm{mg}$ $\mathrm{kg}^{-1}$ in its shoot at $10 \mu \mathrm{M}(=0.6 \mathrm{ppm}) \mathrm{Cu}^{2+}$ in the nutrient solution. A large inter and intraspecific variation of foliar concentrations of $\mathrm{Cu}$ was observed in the supposed hyperaccumulators (Malaisse and Grégoire, 1978; Brooks et al., 1987; Malaisse et al., 1979, 1994, 1999; Paton and Brooks, 1996; Faucon et al., 2007; Faucon et al., 2009). In Crepidorhopalon perennis and $C$. tenuis, the range of $\mathrm{Cu}$ concentrations in leaf was respectively, 500 to $1500 \mathrm{mg} \mathrm{kg}^{-1}$ and 100 to $980 \mathrm{mg} \mathrm{kg}^{-1}$ (Morrison, 1980; Faucon et al., 2007; Faucon et al., 2009).

In this paper, we examine the tolerance and accumulation of copper in controlled conditions in vitro of four metallicolous populations and one non-metallicollous of $C$. tenuis 
and in the single population of $C$. perennis. To our knowledge, this is the first study comparing the $\mathrm{Cu}$ tolerance among metallicolous and non-metallicolous in cuprophytes from Katanga (Democratic Republic of Congo). We specifically address the following questions:(i) is there inter-populational variation in the ability to tolerate $\mathrm{Cu}$ in $C$. tenuis? (ii) do both cuprophytes show an increase in their performance in response to high $\mathrm{Cu}$ concentrations? (iii) can the restricted endemism of $C$. perennis be explained by a cost of tolerance? and (iv) are $C$. perennis et $C$. tenuis guenine $\mathrm{Cu}$ hyperaccumulators and is there any inter-populational variation of the ability to accumulate $\mathrm{Cu}$ in $C$. tenuis?

\section{Material and methods}

\section{Site harvest and plant material}

Seeds were harvested in six populations in Upper-Katanga (Dem. Rep. of Congo) in April 2008 (Table 1) and a pool of representative seeds of the morphological variability of each population was established. Seeds of Crepidorhopalon perennis (CP) were collected in its single population located at the Mine de l'Etoile, $10 \mathrm{~km}$ northeast of Lubumbashi. This endemic cuprophyte is a pioneer species of mining debris or reworked mining substrates and grows on soils having concentrations of $\mathrm{Cu}$ higher than the habitats occupied by the populations of $C$. tenuis (CTC) (range of $\mathrm{Cu}$, for $\mathrm{CP}=2161-55300 \mathrm{mg} \mathrm{kg}^{-1}, \mathrm{CTC}=201-12557$ $\mathrm{mg} \mathrm{kg}$ ) (Faucon et al. 2009, 2011a). Crepidorhopalon tenuis has a much broader geographical range, sometimes occurring on nonmetalliferous soils (Brooks and Malaisse, 1985; Fischer, 1999). Crepidorhopalon tenuis has its ecological optimum in $\mathrm{Cu}$ and $\mathrm{Co}$ rich soils contaminated by metallic atmospheric fallout from ore-smelter or substrate (often mine debris) disturbed and reworked by mining activities (Faucon et al., 2011a). The nonmetallicolous population considered in this study is one of the few known in the plant communities of woodland clearings (miombo) on laterite soil in Katanga.

\section{Method of culture}


In vitro culture was performed in a growth chamber at $20^{\circ} \mathrm{C}$ on Murashige and Skoog (MS) medium (Murashige and Skoog, 1962). MS medium contained EDTA that can reduce bioavailability of copper (Christensen et al., 2008). Seeds were immersed in $70 \%$ ethanol for $5 \mathrm{~min}$, followed by a $10 \mathrm{~min}$ soak in solution of 5\% bleach and $0.1 \%$ SDS (sodium dodecyl sulfate). After three successive washes with sterile ultrapure water, seeds (approximately 30 per dish) were sown on $10 \mathrm{~mL}$ of MS spiked with $\mathrm{CuSO}_{4}$ at a concentration of $60 \mu \mathrm{mol} \mathrm{L}$ (this concentration was chosen based on the results of Lequeux et al. (2010) and Chipeng et al. (2010). A control test (no added $\mathrm{CuSO}_{4}$ ) at $0.1 \mu \mathrm{mol} \mathrm{L}{ }^{-1} \mathrm{CuSO}_{4}$ was also processed in parallel. After one month of incubation, 12 individuals per population were transplanted into pots of $50 \mathrm{~mL}$ of MS, six without added $\mathrm{CuSO}_{4}$ and six containing $60 \mu \mathrm{mol} \mathrm{L}{ }^{-1} \mathrm{CuSO}_{4}$ (n total individuals =72). After eight weeks, the dry mass of shoot plants was measured. The biomass was used as a rough estimate of fitness because it was correlated with the number of seeds ( $\mathrm{r}$ $=0.78, \mathrm{n}=123$ ind. $\mathrm{x}$ three fruits, $\mathrm{P}<0.05)$.

\section{Mineral analysis}

After eight weeks of pot culture, plants were harvested, washed with $1 \%$ Alconox solution (Alconox Inc.) during $2 \mathrm{~min}$, rinsed with demineralised water and then dried at $60^{\circ} \mathrm{C}$ for $48 \mathrm{~h}$ (Faucon et al., 2007). The dried samples were then mineralised and solubilised in a Tecator digestor using a mixture of nitric and perchloric acid (1:1). $\mathrm{Cu}$ concentration was measured by flame atomic absorption spectrometry FAAS (Varian 220).

\section{Statistical analysis}

ANOVA (analysis of variance) provided by Statistica 8 (Statsoft 2008) was used for the statistical analysis. For the biomass analysis, ANOVA with two crossed factors: «treatments » and «populations » (fixed factors) was used. For the analysis of the variation of $\mathrm{Cu}$ concentration in plants one way ANOVA was performed. Significant differences in mean biomass and $\mathrm{Cu}$ concentration among populations and treatments were tested by posthoc multiple comparison (Fisher's Least Significant Difference). 
ANOVA showed significant effects of populations and $\mathrm{Cu}$ concentrations as well as for population*treatment (Table 2). The response to copper varied greatly between populations. Growth was better at $60 \mu \mathrm{mol} \mathrm{L}{ }^{-1}$ of $\mathrm{CuSO}_{4}$ for metallicolous populations $\mathrm{VK}, \mathrm{Ru}, \mathrm{Nm}$ and QG. On the contrary, the best growth was found in the medium without added $\mathrm{CuSO}_{4}$ for the non-metallicolous population Ky. At $60 \mu \mathrm{mol} \mathrm{L}{ }^{-1}$ of $\mathrm{CuSO}_{4}$, $\mathrm{Ky}$ had half that of the control $\left(\mathrm{F}_{1,47}=13.25 ; \mathrm{P}>0.001\right)$ (Figure 1). In addition, chlorosis was present for 5 individuals of Ky on the $\mathrm{CuSO}_{4}$ enriched medium. No significant differences were observed between metallicolous populations when growing in the medium without added $\mathrm{CuSO}_{4}$. At $60 \mu \mathrm{mol} \mathrm{L}$ ${ }^{1}$ of $\mathrm{CuSO}_{4}$, significant difference of biomass existed between populations $\left(\mathrm{F}_{5,21}=8.8\right.$; $\mathrm{P}>0.001$ ) (Figure 1). Biomass of populations changed depending on the $\mathrm{Cu}$ concentration in the medium. When medium without added $\mathrm{CuSO}_{4}$ was used, $\mathrm{VK}>\mathrm{Ky}>\mathrm{Nm}>\mathrm{QG}>\mathrm{Ru}$ whereas on $\mathrm{CuSO}_{4}$ rich medium, $\mathrm{Ru}>\mathrm{Nm}>\mathrm{VK}>\mathrm{QG}>\mathrm{Ky}$. An unexpected result was the large decrease of biomass in the non-metallicolous population $\mathrm{Ky}$ grown on $\mathrm{CuSO}_{4}$ rich medium. In contrast, three out of four metallicolous populations showed a significant increase in biomass in response to $\mathrm{Cu}$ (Figure 1).

\section{Reaction norms of biomass in response to $\mathrm{Cu}$ in C. perennis}

197

Crepidorhopalon perennis did not show any significant difference in biomass on medium without added $\mathrm{CuSO}_{4}$ (mean $\left.=13.8 \mathrm{mg}, \mathrm{SD} \pm 9.8\right)$ and $\mathrm{CuSO}_{4}$ enriched medium $($ mean $=26.2$ mg, $\mathrm{SD} \pm 6.3$ ). On medium without added $\mathrm{CuSO}_{4}, C$. perennis did not show any difference in biomass compared to the non-metallicolous population of $C$. tenuis $\mathrm{Ky}$ (mean $=27 \mathrm{mg}$, SD $\pm 20.5)\left(\mathrm{F}_{5,26}=2.1 ; \mathrm{ns}\right)$.

\section{Variation of $\mathrm{Cu}$ concentration in shoot}

A significant difference in $\mathrm{Cu}$ concentration in plant shoots was shown among populations $\left(\mathrm{F}_{5,17}=7.8(\mathrm{P}<0.001)\right)($ Figure 2$)$. The non-metallicolous population Ky showed the highest value (mean $\left.=115 \mu \mathrm{g} \mathrm{mg}^{-1}, \mathrm{SD} \pm 17.6\right)$, followed by $\mathrm{Ru}\left(\right.$ mean $=80 \mu \mathrm{g} \mathrm{mg}^{-1}, \mathrm{SD} \pm 34$ ) (Figure 2) whereas $C$. perennis showed $\mathrm{Cu}$ concentration below $40 \mu \mathrm{g} \mathrm{mg}^{-1}$. 


\section{Discussion}

\section{Between population variation of copper tolerance}

213

Crepidorhopalon perennis and all populations of $C$. tenuis from metal rich soil grew as well or better in the $\mathrm{CuSO}_{4}$ enriched medium compared to the control treatment, indicating that they are highly tolerant to copper. In the same experimental conditions, growth of non tolerant species was negatively affected at concentrations as low as $5 \mu \mathrm{mol} \mathrm{L}{ }^{-1}$ of $\mathrm{CuSO}_{4}$ e.g. in Nicotiana plumbaginifolia (Chipeng et al., 2010) and Arabidopsis thaliana (Lequeux et al., 2010). Conversely, the population from normal soil (Kyembe) is significantly less tolerant, and strongly affected by $60 \mu \mathrm{mol} \mathrm{L} \mathrm{L}^{-1}$ of $\mathrm{CuSO}_{4}$. This suggests that $C$. tenuis is not constitutively tolerant to copper. Instead, the broad ecological amplitude of the species in Katanga may be due to its genetic variation of copper tolerance. The results suggest that metal tolerance in population from metal-rich soil has evolved in response to natural selection. This pattern of variation has been found in a number of pseudometallophytes, in which coppertolerant ecotypes have been reported (Gregory and Bradshaw, 1965; Antonovics et al., 1971; Kruckeberg and Wu, 1992; Gonnelli et al., 2001; Ginocchio et al., 2002; Nicholls and McNeilly, 1985; Nordal et al., 1999; Macnair et al., 2000). Our results represent the first confirmation of the existence of such ecotypes in metallophytes from Katanga. However, local adaptation remains to be formally confirmed by reciprocal transplantation.

However, variation in tolerance among populations from metal-rich soil does not appear to be correlated to copper concentration in their native soil (Table 3). Thus, Ru population, with the highest degree of tolerance, originates from the site with the lowest $\mathrm{Cu}$ concentration in the soil. However, copper bioavailability and toxicity is strongly influenced by physical and chemical properties of soil, including pH and Mn concentration (e.g. Faucon et al., 2009, 2011b). Therefore, other elements in the soil may mitigate $\mathrm{Cu}$ toxicity and relax selection pressure for enhanced tolerance. Other factors can also explain variation in tolerance among populations, including population age (Wu et al., 1975). Crepidorhopalon tenuis appears to have strongly expanded its range in Katanga in response to mining activities and many populations may be of relatively recent origin and not yet in equilibrium with local soil conditions. 


\section{Cost of copper tolerance and growth stimulation}

242 An interesting result is the enhanced growth at $60 \mu \mathrm{mol} \mathrm{L}{ }^{-1}$ of $\mathrm{CuSO}_{4}$ compared to the

243

244

245 control, which was observed in 4 out of 5 populations from metal-rich soil. This finding is in agreement with the field observations indicating that plant size and population density are much larger on metal rich soil compared to normal soil (Faucon et al., 2009, 2011a). Because the plants studied here have been grown in axenic conditions, a protective effect against pathogens cannot be invoked, which indicates that $C$. tenuis and $C$. perennis actually have elevated requirements of $\mathrm{Cu}$. Growth stimulation by elevated concentrations of $\mathrm{Cu}$ has only rarely been reported, for example in the copper-moss Scopelophila cataractae (Shaw, 1994), the Katangan cuprophyte (Haumaniastrum katangense (Chipeng et al., 2010) and a couple of Elsholtzia species in China (Lou et al., 2004; Jiang et al., 2008).

These results can also be interpreted as evidences for cost of metal tolerance, i.e. on "normal" medium, performance of $\mathrm{Cu}$-tolerant populations is lower than the non-tolerant population in C. tenuis. Such cost has only been demonstrated in experimental conditions in few species, e.g. Mimulus guttatus for the Cu tolerance (Allen and Sheppard, 1971; Macnair et al., 2000). Other works failed to reveal such fitness costs (e.g. Nicholls and McNeilly, 1985; Dechamps et al., 2006).

\section{Crepidorhopalon perennis, an absolute metallophyte}

Absolute metallophytes, i.e. species that are currently known only from metal rich soil, may not be able to grow on normal soil (Tadros, 1957). Based on this assumption, the elevated cost of tolerance would account for the restricted niche. The cost of tolerance means that metal-tolerant populations show lower fitness on non-metalliferous soil than non-tolerant populations and vice versa on copper soil. It seems that essential needs in metals are more important for tolerant populations than for non-tolerant plants (Macnair et al., 2000). Our failure to cultivate $C$. perennis on normal soil, in spite of repeated trials, indicates that such cost might indeed be involved (Faucon, 2009). However, in this work in axenic conditions, $C$. perennis did not grow significantly less well in normal soil. This result does not support the hypothesis of a high cost of tolerance in this species and hence it should be taken with 
caution. Firstly, the sample size was relatively low ( $\mathrm{n}=6$ individuals per population and per treatment); secondly, there was only one contaminated treatment in this study and it is not impossible that the physiological optimum of $C$. perennis is actually higher than the concentration of $\mathrm{Cu}\left(60 \mu \mathrm{mol} \mathrm{L}^{-1}\right)$. Furthermore, apart from copper, tolerance of other metals might be involved, most notably of cobalt, which is present at high concentration at the Mine de l'Etoile, the native site of $C$. perennis. Limited dispersal ability is unlikely, as newly formed malachite deposits at the Mine de l'Etoile are readily colonised by this species. Crepidorhopalon species have tiny seeds, which are probably easily transported by the wind. Finally, the narrow realised niche may be related to limiting biotic factors. Cuprophytes appear specifically to be susceptible to soil pathogenic fungi (Malaisse and Brooks, 1982; Paton and Brooks, 1996; Chipeng et al., 2010), which may be explained by the relaxed pressure of pathogenic fungi on metal-rich soil (Tadros, 1957).

\section{Copper accumulation or exclusion?}

Crepidorhopalon perennis and $C$. tenuis have been reported as $\mathrm{Cu} / \mathrm{Co}$ hyperaccumulators (Duvigneaud, 1958; Malaisse and Grégoire, 1978; Brooks et al., 1987). In this study, the copper concentrations in shoot were always below the conventional hyperaccumulation threshold (1000 $\left.\mathrm{mg} \mathrm{kg}^{-1}\right)$. This result is in agreement with other studies in which cuprophytes did not show hyperaccumulation when cultivated in controlled conditions (Morrison et al., 1979, 1981; Chipeng et al., 2010; Peng et al., in press). They suggest that these species are excluders rather than hyperaccumulators. The high foliar concentrations of $\mathrm{Cu}$ found in leaves collected in the field (Duvigneaud, 1958; Malaisse and Grégoire, 1978; Brooks et al., 1987) may in part be due to surface contamination by dust (Faucon et al., 2007). However, foliar concentrations in this study are much lower than those found in carefully cleaned samples on the field (Faucon et al., 2007, 2009) (Table 3), which indicates that copper accumulation may be expressed only under specific conditions that are difficult to mimic in cultivation as in this study. Variation of copper concentrations in shoots of these species should be studied in controlled conditions with $\mathrm{Cu}$ contaminated substrate considering physical conditions and fertility relatives of soils where these species grow.

We also have shown that competition with $\mathrm{Co}$ and $\mathrm{Mn}$ strongly influences the patterns of $\mathrm{Cu}$ accumulation (Faucon et al., 2009), interactions with microorganisms might also be involved 
(Fomina et al., 2005; Toler et al., 2005) and explain the absence of high $\mathrm{Cu}$ concentrations in shoot in these culture conditions. The $\mathrm{pH}$ is likely to be the most important physicochemical parameter controlling metal fractionation and mobility. Even though the stability of colloids (i.e. either organic or inorganic, which are microscopic metals adsorbent phases and therefore govern, via their mobilization in soils, their fate and/or bioavailability) according to $\mathrm{pH}$ is well documented, few studies were dedicated to the understanding of colloids and associated metal release from soils and water with regard to $\mathrm{pH}$ change and thus mobility/bioavailability leading to accumulation in plants (e.g. Pourret et al., 2010). In the future, it would be of interest to examine concentration of bioavailable $\mathrm{Cu}$ in relation with $\mathrm{Cu}$ accumulation in plants to understand the high $\mathrm{Cu}$ concentrations and their variation in $C$. tenuis and $C$. perennis observed in natura (Table 3 ).

Even though copper concentrations in leaves are low, they appear to be related to tolerance; the non tolerant population of $C$. tenuis (Kyembe) has the highest accumulation in leaves. This may indicate that elevated tolerance in populations from metal-rich soils is achieved through enhanced capacity to restrict $\mathrm{Cu}$ uptake and/or translocation to shoot. Similar results have been obtained in copper tolerant ecotypes of other species (Kruckeberg and Wu, 1992; Schat et al., 1993; Ouzounidou et al., 1994; Gonnelli et al., 2001; Weng et al., 2005, but see Macnair, 1981)

\section{Conclusion}

Crepidorhopalon perennis and C. tenuis, two species with high affinity for $\mathrm{Cu}$-rich soil in Katanga, have tolerance to $\mathrm{Cu}$, which is probably associated to a copper exclusion strategy. The pattern of variation in tolerance in C. tenuis, suggests that populations from metal rich soil have been subjected to directional selection for increased tolerance. Based on experimental data, we can conclude that $C$. tenuis and $C$. perennis, together with Haumaniastrum katangense can be considered as promising study models for the evolution of copper tolerance in the flora of SC Africa. 


\section{Acknowledgements}

The Belgian Fund for Scientific Research (FRS-FNRS) is acknowledged for financial support to MPF, who was a research fellow of the Fonds pour la Recherche dans l'Industrie et l'Agriculture (FRIA, Belgium). We are grateful to Petru Jitaru from Unit Hydrogeochemical Interaction Soil-Environment (LaSalle Beauvais, France) for reviewing the English.

This work is part of the research project 2.4.582.09F funded by the FRS-FNRS and of the "Projet interuniversitaire ciblé" (Project REMEDLU) funded by the Coopération Universitaire au Développement (CUD, Belgium).

\section{Bibliography}

Allen, W.R., Sheppard, P.M., 1971. Copper tolerance in some Californian populations of the monkey flower Mimulus guttatus. Proceedings of the Royal Society of London 177, 177196.

Alloway, B.J., 1995. Heavy Metals in Soils, $2^{\text {nd }}$ ed. Blackie, Glasgow, 368p.

Antonovics, J., Bradshaw, A.D., Turner, R.G., 1971. Heavy metal tolerance in plants. Advances in Ecological Research 7, 1-85.

Baize, D., Tercé, M., 2002. Les éléments traces métalliques dans les sols: approches fonctionnelles et spatiales, INRA, Edition Quae, 565p.

Baker, A.J.M., McGrath, S.P., Reeves, R.D., Smith, J.A.C., 2000. Metal hyperaccumulator plants: a review of the ecology and physiology of a biological resource for phytoremediation of metal-polluted soils. In: Bañuelos $\mathrm{G}$ and Terry $\mathrm{N}$ (eds) Phytoremediation of contaminated soil and water. CRC Press LLC, Boca Raton, FL, USA, 85-108.

Baker, A.J.M., Brooks, R.R., 1989. Terrestrial higher plants which hyperaccumulate metallic elements: A review of their distribution, ecology and phytochemistry. Biorecovery, 1, 81126. 
Baker, A.J., Brooks, R.R., Pease, A.J., Malaisse, F., 1983. Studies on copper and cobalt tolerance in the three closely related taxa within the genus Silene L. (Caryophyllaceae) from Zaïre. Plant and Soil 73, 377-385.

Brooks, R.R., Malaisse, F., 1990. Metal-enriched sites in South. Central Africa. In Shaw AJ, ed. Heavy Metal Tolerance In Plants: Evolutionary aspects. CRC Press, Boca Raton, USA 53-73.

Brooks, R.R., Naidu, S., Malaisse, F., Lee, J., 1987. The elemental content of metallophytes from the copper/cobalt deposits of Central Africa. Bulletin de la Société Royale Botanique de Belgique 119, 179-191.

Brooks RR, Malaisse F (1985) The Heavy Metal-Tolerant Flora of South-central Africa - A Multidisciplinary Approach. Balkema. Rotterdam. 199 pp.

Chipeng, K.F., Hermans, C., Colinet, G., Faucon, M.P., Ngongo Luhembwe, M., Meerts, P., Verbruggen, N., 2010. Copper tolerance in the cuprophyte Haumaniastrum katangense (S. Moore) P.A. Duvign. and Plancke. Plant and Soil 328, 235-244.

Christensen, B., Sriskandarajah, S., Serek, M., Müller, R., 2008. In vitro culture of Hibiscus rosa-sinensis L.: Influence of iron, calcium and BAP on establishment and multiplication. Plant Cell, Tissue and Organ Culture 93, 151-161.

Dechamps, C., Lefèbvre, C., Noret, N., Meerts, P., 2006. Reaction norms of life history traits in response to zinc in Thlaspi caerulescens from metalliferous and nonmetalliferous sites. New Phytologist 173, 191-198.

Duvigneaud, P., Denaeyer-De Smet, S., 1963. Cuivre et végétation au Katanga. Bulletin de la Société Royale Botanique de Belgique 96, 92-231.

Duvigneaud, P., 1958. The vegetation of Katanga and its metalliferous soils. Bulletin de la Société Royale Botanique de Belgique 90, 127-286.

Ernst, W.H.O., 1990. Mine vegetation in Europe. In Heavy Metal Tolerance in Plants: Evolutionary Aspects. Shaw J. A. (ed.). CRC Press, New York 18, 21-38.

Ernst, W.H.O., 1974. Schwermetallvegetation der Erde. Fischer Verlag, Stuttgart, 194p. 
Faucon, M.P., Muding Tshilong, B., Van Rossum, F., Meerts, P., Shutcha, M., Mahy, G., Conservation of the critically endangered metallophyte Crepidorhopalon perennis: evaluation of hybridisation risk with the related C. tenuis. Biotropica, in press. DOI: 10.1111/j.1744-7429.2011.00845.x

Faucon, M.P., Parmentier, I., Colinet, G., Mahy, G., Ngongo Luhembwe, M., Meerts, P., 2011a. May rare metallophytes benefit from disturbed soils following mining activity? The case of the Crepidorhopalon tenuis in Katanga (DRCongo). Restoration Ecology 19, 333-343.

Faucon, M.P., Colinet, G., Jitaru, P., Verbruggen, N., Shutcha, M., Mahy, G., Meerts, P., Pourret, O., 2011b. Relation between Cobalt Fractionation and its Accumulation in Metallophytes from South of Central Africa. Mineralogical Magazine 75, 832.

Faucon, M.P., Meersseman, A., Shutcha, M., Mahy, G., Malaisse, F., Ngongo Luhembwe, M., Meerts, P., 2010. Copper endemism in the Congolese flora: A database of copper affinity and conservation value of cuprophytes. Plant Ecology and Evolution 143, 5-20.

Faucon, M.P., Colinet, G., Mahy, G., Ngongo Luhembwe, M., Verbruggen, N., Meerts, P., 2009. Soil influence on $\mathrm{Cu}$ and $\mathrm{Co}$ uptake and plant size in the cuprophytes Crepidorhopalon perennis and C. tenuis (Scrophulariaceae) in SC Africa. Plant and Soil 317, 201-212.

Faucon, M.P., Shutcha, M., Meerts, P., 2007. Revisiting copper and cobalt concentrations in supposed hyperaccumulators from SC Africa: influence of washing and metal concentrations in soil. Plant and Soil 301, 29-36.

Fischer, E., 1999. Scrophulariaceae (première partie). Ed. P. Bamps. Flore d'Afrique Centrale (Congo Kinshasa-Rwanda-Burundi), Meise, Belgium, pp. 1-217.

Fomina, M.A., Alexander, I.J., Colpaert, J.V., Gadd, G.M., 2005. Solubilization of toxic metal minerals and metal tolerance of mycorrhizal fungi. Soil Biology and Biochemistry $37,851-866$.

Ginocchio, R., Toro, I., Schnepf, D., 2002. Copper tolerance in populations of Mimulus luteus var. variegatus exposed and non exposed to copper pollution. Geochemistry: Exploration, Environment, Analysis 2, 151-156. 
Gonnelli, C., Galardi, F., Gabbrielli, R., 2001. Nickel and copper tolerance and toxicity in three Tuscan populations of Silene paradoxa. Physiologia Plantarum 113, 507-514.

Gregory, R.P.G., Bradshaw, A.D., 1965. Heavy metal tolerance in populations of Agrostis tenuis Sibth. and other grasses. New Phytologist 64, 131-14.

Harper, F.A., Smith, S.E., Macnair, M.R., 1997. Can an increased copper requirement in copper-tolerant Mimulus guttatus explain the cost of tolerance? I. Vegetative growth. New Phytologist 136, 455-467.

Harper, F.A., Smith, S.E., Macnair, M.R., 1998. Can an increased copper requirement in copper-tolerant Mimulus guttatus explain the cost of tolerance? II. Reproductive phase. New Phytologist 140, 637-654.

Jiang, L.Y., Yang, X.E., Chen, J.M., 2008. Copper tolerance and accumulation of Elsholtzia splendens Nakai in a pot environment. Journal of Plant Nutrition 31, 1382-1392.

Kazakou, E., Dimitrakopoulos, P.G., Baker, A.J.M., Reeves, R.D., 2008. Hypotheses, mechanisms and trade-offs of tolerance and adaptation to serpentine soils: from species to ecosystem level. Biological Reviews 83, 485-508.

Küpper, H., Götz, B., Mijovilovich, A., Küpper, F.C., Meyer-Klaucke, W., 2009. Complexation and toxicity of copper in higher plants. I. Characterization of copper accumulation, speciation, and toxicity in Crassula helmsii as a new copper accumulator. Plant Physiology 151, 702-714.

Kruckeberg, A.L., Wu, L., 1992. Copper tolerance and copper accumulation of herbaceous plants colonizing inactive California copper mines. Ecotoxicology and Environmental Safety 23, 307-331.

Lequeux, H., Hermans, C., Lutz, S., Verbruggen, N., 2010. Response to copper excess in Arabidopsis thaliana: Impact on the root system architecture, hormone distribution, lignin accumulation and mineral profile. Plant Physiology and Biochemistry 48, 673-682.

Lou, L.Q., Shen, Z.G., Li, X.D., 2004. The copper tolerance mechanisms of Elsholtzia haichowensis, a plant from copper-enriched soils. Environmental and Experimental Botany 51, 111-120. 
Macnair, M.R., 1981. The uptake of copper plants of Mimulus guttatus differing in genotype primarly at a single major copper tolerance locus. New Phytologist 88, 723-730.

Macnair, M.R., 1983. The genetic control of copper tolerance in the yellow monkey flower. Mimulus guttatus. Heredity 50, 283-293.

Macnair, M.R., Christie, 1983. Reproductive isolation as a pleitropic effect of copper tolerance in Mimulus guttatus? Heredidy 50, 295-302.

Macnair, M.R., Gardner, M., 1998. The evolution of edaphic endemics. In : Endless forms, species and speciation (eds. Howard DJ, Berlocher SH), Oxford University Press, New York, 157-171.

Macnair, M.R., Tilstone, G.H., Smith, S.E., 2000. The genetics of metal tolerance and accumulation in higher plants. In: Phytoremediation of Contaminated Soil and Water (eds. Terry N., Banuelos G., Vangronsveld J.), CRC Press, Boca Raton, 235-250.

Malaisse, F., Baker, A.J.M., Ruelle, S., 1999. Diversity of plant communities and leaf heavy content at Luiswishi copper/ cobalt mineralization, Katanga, Dem. Rep. Congo. Biotechnologie Agronomie Société Environnement 3, 104-114.

Malaisse, F., Brooks, R.R., Baker, A.J.M., 1994. Diversity of vegetation communities in relation to soil heavy metal content at the Shinkolobwe copper/cobalt/uranium mineralization, Upper Shaba, Zaïre. Bulletin de la Société Royale Botanique de Belgique 127, 3-16.

Malaisse, F., Brooks, R.R., 1982. Colonisation of modified metalliferous environments in Zaire by the copper flower Haumaniastrum katangense. Plant and Soil 64, 289-293.

Malaisse, F., Grégoire, J., Morrison, R.S., Brooks, R.R., Reeves, R.D., 1979. Copper and cobalt in vegetation of Fungurume, Shaba Province, Zaïre. Oikos 33, 472-478.

Malaisse, F., Grégoire, J., 1978. Contribution à la phytogéochimie de la Mine de l'Étoile (Shaba, Zaïre). Bulletin de la Société Royale Botanique de Belgique 111, 252-260.

McNeilly, T., Bradshaw, A.D., 1968. Evolutionary processes in populations of copper tolerant Agrostis tenuis Sibth. Evolution, Lancaster, 22, 108-118. 
Morrison, R.S., 1980. Aspects of the accumulation of Cobalt, Copper and Nickel by Plants, Ph.D. thesis. Massey University, Palmerston North, New Zealand, pp.

Morrison, R.S., Brooks, R.R., Reeves, R.D., Malaisse, F., Horowitz, P., Aronson, M., Merriam, G.R., 1981. The diverse chemical forms of heavy metals in tissues extracts of some metallophytes from Shaba province, Zaïre. Phytochemistry 20, 455-458.

Morrison, R.S., Brooks, R.R., Reeves, R.D., Malaisse, F., 1979. Copper and cobalt uptake by metallophytes from Zaïre. Plant and Soil 53, 535-539.

Murashige, T., Skoog, F., 1962. A revised medium for rapid growth and bioassays with tobacco tissue culture. Physiologia Plantarum 15, 437-497.

Nicholls, M.K., McNeilly, T., 1985. The performance of Agrostis capillaris L. Genotypes, differing in copper tolerance, in ryegrass swards on normal soils. New Phytologist 101, 207-217.

Nordal, I., Haraidsen, K.B., Ergon, A., Eriksen, A.B., 1999. Copper resistance and genetic diversity in Lychnis alpina (Caryophyllaceae) populations on mining sites. Folia Geobotanica 34, 471-481.

Ouzounidou, G., Symeonidis, L., Babalonas, D., Karataglis, S., 1994. Comparative responses of a copper-tolerant and a copper sensitive population of Minuartia hirsuta to copper toxicity. Journal of Plant Physiology 144, 109-115.

Paton, A., Brooks, R.R., 1996. A re-evaluation of Haumaniastrum species as geobotanical indicators of copper and cobalt. Journal of Geochemical Exploration 56, 37-45.

Peng, H., Wang-Müller, Q., Witt, T., Malaisse, F., Küpper, H., 2012. Differences in copper accumulation and copper stress between eigth populations of Haumaniastrum katangense. Environmental and Experimental Botany, 1-25, in press.

Pourret, O., Gruau, G., Dia, A., Davranche, M., Molénat, J., 2010. Colloidal control on the distribution of rare earth elements in shallow groundwaters. Aquatic Geochemistry, 16, 31-59.

Reeves, R.D., 2006. Hyperaccumulation of trace elements by plants In: Morel JL, Echevarria G. and Goncharova N (eds) Phytoremediation of Metal-Contaminated Soils. NATO 
Science Series: IV: Earth and Environmental Sciences Volume 68. Springer, New York, pp 25-52.

Reeves, R.D., Baker, A.J.M., 2000. Metal-accumulating plants. In: Raskin I and Ensley BD (eds) Phytoremediation of toxic metals. Wiley, New York, pp 193-221.

Schat, H., Ten Bookum, W.M., 1992. Genetic control of copper tolerance in Silene vulgaris. Heredity 63, 219-229.

Schat, H., Kuiper, E., Ten Bookum, W.M., Vooijs, R., 1993. A general model for the genetic control of copper tolerance in Silene vulgaris: evidence from crosses between plants from different tolerant populations. Heredity 70, 142-147.

Shaw, A.J., 1994. Adaptation to metals in widespread and endemic plants. Environmental Health Persectives 102, 105-108.

Smith, K.S., Huyck, H.L.O., 1999. An overview of the abundance, relative mobility, bioavailability, and human toxicity of metals. In ed. G. S. Plumlee and M. J. Logsdon, The Environmental Geochemistry of Mineral Deposits, Society of Economic Geologists, Vol. 6A, pp. 29-70.

Tadros, T.M., 1957. Evidence of the presence of an edapho-biotic factor in the problem of serpentine tolerance. Ecology 38, 14-23.

Toler, H.D., Morton, J.B., Cumming, J.R., 2005. Growth and metal accumulation of mycorrhizal sorghum exposed to elevated copper and zinc. Water, Air, and Soil Pollution $164,155-172$.

Weng, G., Wu, L., Wang, Z., Luo, Y., Christie, P., 2005. Copper uptake by four Elsholtzia ecotypes supplied with varying levels of copper in solution culture. Environment International 31, 880-884.

Wu, L., Bradshaw, A.D., Thurman, D.A., 1975. The potential for evolution of heavy metal tolerance in plants. III. The rapid evolution of copper tolerance in Agrostis Stolonifera. Heredity 34, 165-187. 
Table 1 Location and habitats description of studied populations. $\mathrm{CP}=$ Crepidorhopalon perennis; $\mathrm{CTC}=$ C. tenuis from copper soil and $\mathrm{CTN}=C$. tenuis from normal soil.

532

533 Table 2 Biomass variation of $C$. tenuis populations (four metallicolous populations and one non-metallicolous) and single population of $C$. perennis on in vitro culture with two treatments ( $\left(0\right.$ and $60 \mu \mathrm{mol} \mathrm{L}{ }^{-1}$ of $\left.\mathrm{CuSO}_{4}\right)$

Table 3 Copper and cobalt levels of plants and soils in natura in Crepidorhopalon tenuis from normal soil (CTN), C. tenuis from copper soils (CTC) and C. perennis (CP) (Faucon et al. 2009) (mean and min-max). $\mathrm{Cu}$ and $\mathrm{Co}$ concentrations in soil with ammonium acetate -EDTA $1 \mathrm{M}(\mathrm{pH} 4.65)$ extraction.

541

542

543

544

545

546

547

548

549

550

551

552

553 
Table 1

556

\begin{tabular}{|c|c|c|c|c|}
\hline Sites & Type & Habitat description & Altitude (m) & Co-ordinates \\
\hline Etoile (E) & $\mathrm{CP}$ & $\begin{array}{l}\text { Natural copper hill; substrate locally } \\
\text { disturbed by mining }\end{array}$ & 1280 & $\begin{array}{l}\mathrm{S} 11,63562^{\circ} \\
\mathrm{E} 27,58448^{\circ}\end{array}$ \\
\hline Niamumenda (Nm) & CTC & $\begin{array}{l}\text { Natural copper hill; substrate locally } \\
\text { disturbed by mining }\end{array}$ & 1340 & $\begin{array}{l}\mathrm{S} 11,60492^{\circ} \\
\mathrm{E} 27,29400^{\circ}\end{array}$ \\
\hline Ruashi (Ru) & СTC & $\begin{array}{l}\text { Anthropic site: recolonization of } \\
\text { mine deposits }\end{array}$ & 1300 & $\begin{array}{l}\mathrm{S} 11,62645^{\circ} \\
\mathrm{E} 27,56328^{\circ}\end{array}$ \\
\hline $\begin{array}{l}\text { Quartier } \\
\text { Gécamines (QG) }\end{array}$ & CTC & $\begin{array}{l}\text { Anthropic site: normal soil } \\
\text { contaminated by atmospheric fallout } \\
\text { from ore-smelter, moist environment }\end{array}$ & 1220 & $\begin{array}{l}\mathrm{S} 11,70760^{\circ} \\
\mathrm{E} 27,42985^{\circ}\end{array}$ \\
\hline $\begin{array}{l}\text { Vallée Karavia } \\
\text { (VK) }\end{array}$ & CTC & $\begin{array}{l}\text { Anthropic site: normal soil } \\
\text { contaminated by atmospheric fallout } \\
\text { from ore-smelter, moist environment }\end{array}$ & 1230 & $\begin{array}{l}\mathrm{S} 11,67270^{\circ} \\
\mathrm{E} 27,43091^{\circ}\end{array}$ \\
\hline Kyembe (Ky) & CTN & $\begin{array}{l}\text { Natural site: forest clearing (miombo) } \\
\text { on lateritic gravel }\end{array}$ & 1190 & $\begin{array}{l}\text { S } 11,11269^{\circ} \\
\text { E } 27,25825^{\circ}\end{array}$ \\
\hline
\end{tabular}

557

558

559

560

561

562

563

564

565

566

567

568

569

570 


\section{Table 2}

573

574

\begin{tabular}{lccl}
\hline Sites & Df & F & P \\
\hline Population & 5 & 3.1 & $\mathrm{P}<0.05$ \\
Treatment & 1 & 13.3 & $\mathrm{P}<0.001$ \\
Treatment*population & 5 & 6.4 & $\mathrm{P}<0.001$ \\
Error & 47 & & \\
\hline
\end{tabular}

575

576

577

578

579

Table 3

\begin{tabular}{|c|c|c|c|c|c|}
\hline Sites & Populations & Co $\mu \mathrm{g} \mathrm{g}^{-1}$ soil & Co $\mu \mathrm{g} \mathrm{g}^{-1}$ plant & $\mathrm{Cu} \mu \mathrm{g} \mathrm{g}^{-1}$ soil & $\mathrm{Cu} \mu \mathrm{g} \mathrm{g}^{-1}$ plant \\
\hline $\mathbf{E}$ & $\mathrm{CP}$ & $275(98-572)$ & $397(61-1105)$ & $11278(2161-55300)$ & $394(80-1380)$ \\
\hline Nm & CTC & $23(2-98)$ & $19(8-58)$ & $3428(382-18144)$ & $660(84-2524)$ \\
\hline $\mathbf{R u}$ & CTC & $54(9-278)$ & $130(24-605)$ & $991(71-5869)$ & $190(59-412)$ \\
\hline QG & CTC & $6(0,8-16)$ & 47 (24-99) & $1082(224-2727)$ & $100(41-338)$ \\
\hline VK & CTC & $20(7-44)$ & $58(14-176)$ & $3544(362-8189)$ & $100(34-211)$ \\
\hline Ky & $\mathrm{CTN}$ & $<1$ & $<5$ & $1.6(0.8-2.1)$ & $22(8-93)$ \\
\hline
\end{tabular}

580

581

582

583

584

585

586

587

588

589 
590 Figure 1 Biomass of metallicolous populations (Nm, QG, VK and Ru) and non591 metallicolous (Ky) in Crepidorhopalon tenuis and in C.perennis $(\mathrm{CP})$ at 0 et $60 \mu \mathrm{mol} \mathrm{L}^{-1}$ 592 of $\mathrm{CuSO}_{4}$. $\mathrm{N}=6$ per populations and treatment; error bars = standard deviation. For each 593 population at $60 \mu \mathrm{mol} \mathrm{L}^{-1}$ of $\mathrm{CuSO}_{4}$, means with the same letters are not significant (LSD 594 Fisher test). The two treatments per population were compared One way anova $* * *=$ $595 \mathrm{P}<0.001 ; * *=\mathrm{P}<0.01 ; * \mathrm{P}<0.05$ between the treatments for the same population.

Figure 2 Copper concentrations in plant shoot of metallicolous populations (Nm, QG, VK and Ru) and non-metallicolous (Ky) in Crepidorhopalon tenuis and in C. perennis (CP) on growing medium enriched at $60 \mu \mathrm{mol} \mathbf{L}^{-1}$ of $\mathrm{CuSO}_{4} \mathrm{~N}=6$ per population ; error 600 bars $=$ standard deviation. The means with the same letters are not significant (LSD Fisher 601 test).

602

603

604

605

606

607

608

609

610

611

612

613

614

615 


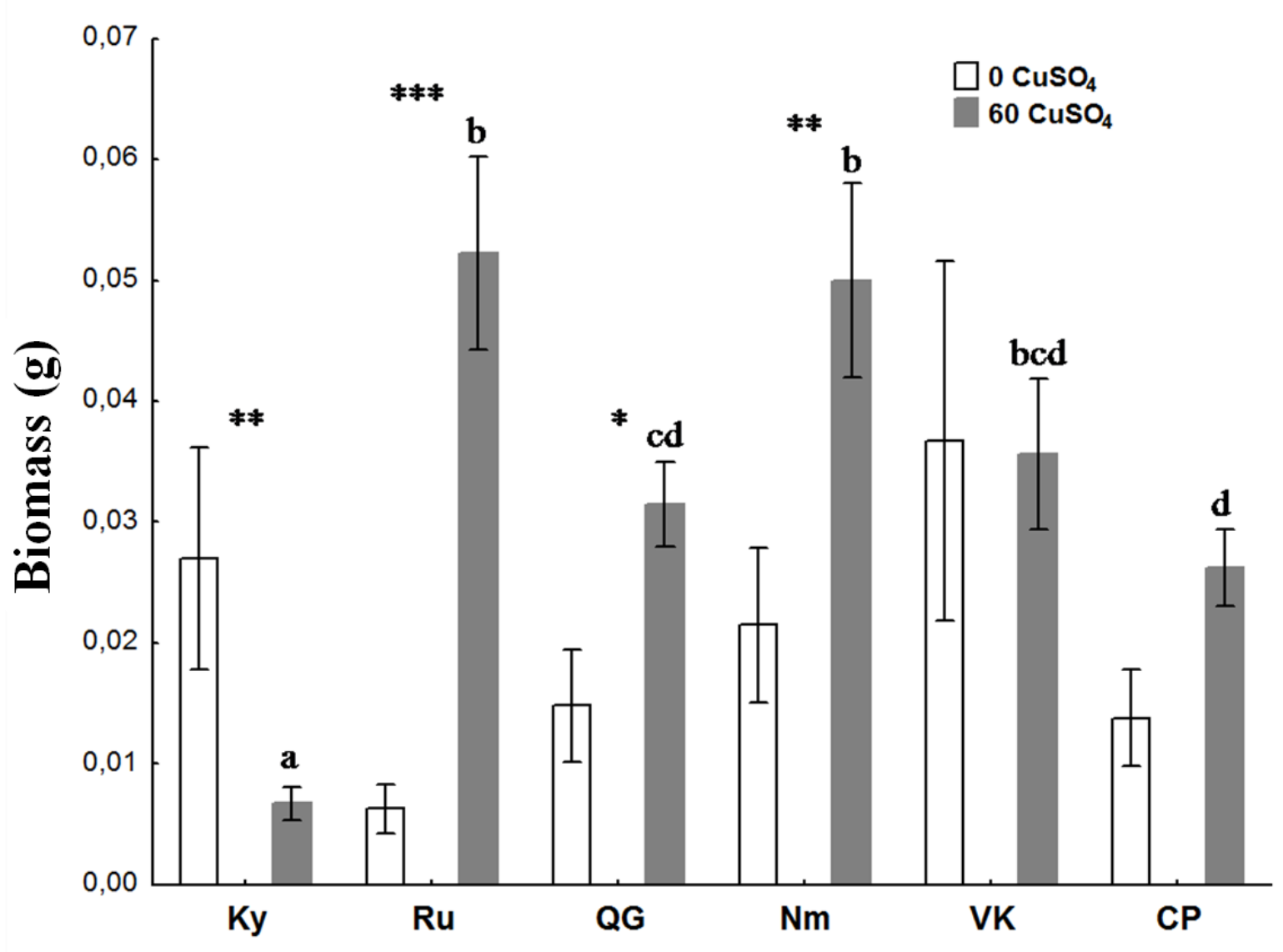

619

620

621

622

623

624

625

626

627

628

629

630

631 
632

633 Figure 2

634

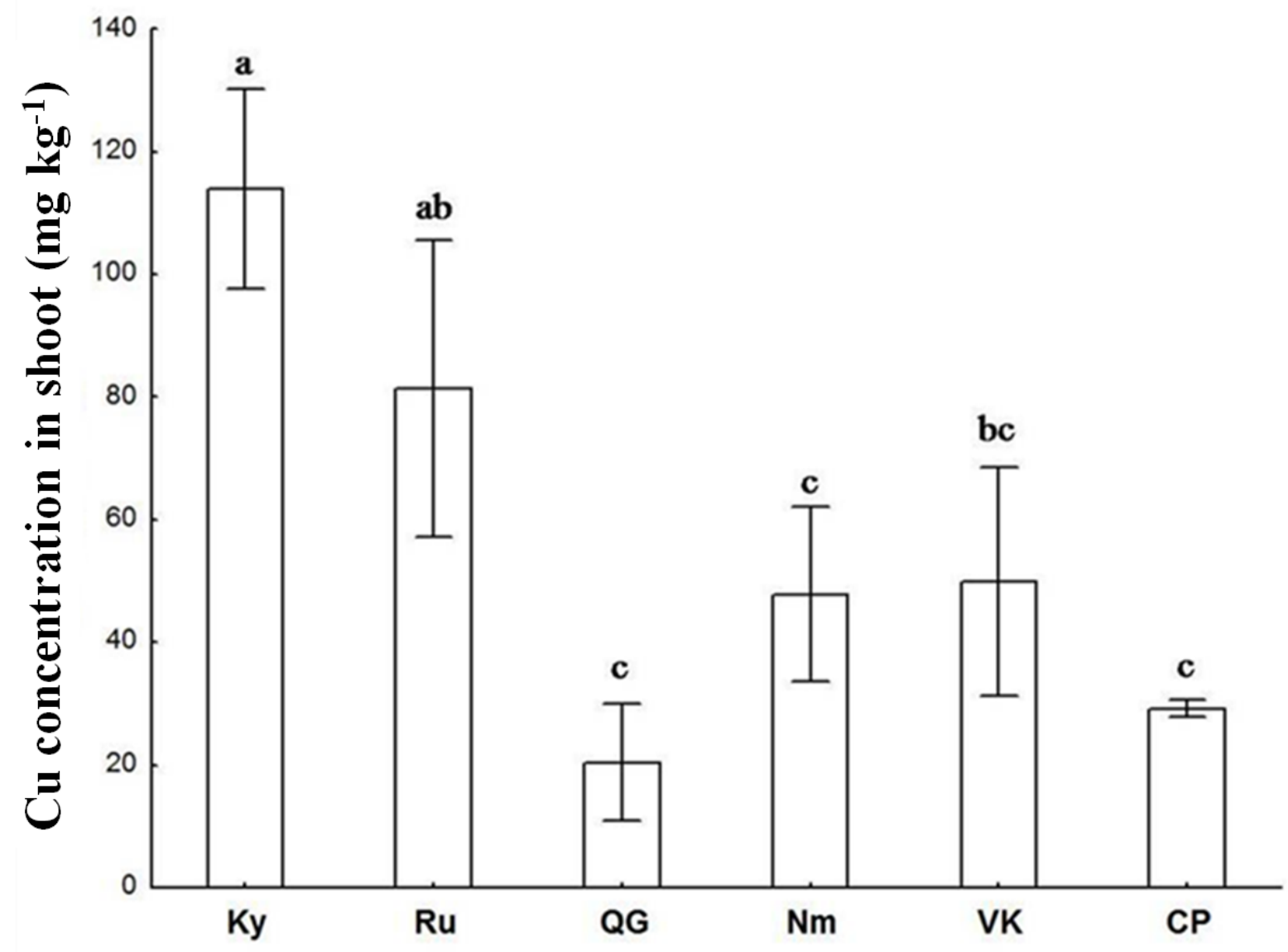

635 